\title{
PENGEMBANGAN MODUL PEMBELAJARAN IPA BERBASIS EXAMPLE NON EXAMPLE MATERI PEMANASAN GLOBAL UNTUK SISWA KELAS VII SMPN 05 SELUMA
}

\author{
Tri Afeni, Asiyah, Nurlia Latipah \\ Program Studi Pendidikan IPA IAIN Bengkulu. \\ Jl. Raden Fatah, Pagar dewa, Bengkulu 38211, Indonesia \\ E-mail triafeni11@gmail.com
}

\begin{abstract}
ABSTRAK
Penelitian ini dilaksanakan di SMPN 05 seluma dengan meneliti anak kelas VIII pada semester 1 Tahun ajaran 2020/2021 yang berjumlah 23 anak. Tujuan penelitian ini adalah untuk mengembangkan modul pembelajaran berbasis example non example yang layak dan praktis yang digunakan setelah validasi oleh beberapa ahli dan uji respon oleh siswa dan guru. Metode penelitian menggunakan model pengembangan Borg \& Gall yang kemudian dibatasi hingga 8 tahapan dan dibatasi menghasilkan tahapan pengembangan modul pembelajaran IPA yaitu: Potensi dan masalah, Pengumpulan data, Desain produk, Validasi desain, Validasi materi, Validasi bahasa, Validasi produk, Uji respon siswa, Revisi produk. Penelitian ini dibatasi pada tahap uji coba lapangan terbatas yaitu kelayakan dan keperaktisan modul. Instrumen yang digunakan adalah angket uji kelayakan modul dan angket respon siswa dan guru. Subjek penelitian adalah 5 dosen IAIN Bengkulu dan 1 guru mata pelajaran yang terdiri atas 2 validasi bahasa, 2 validasi materi, 2 validasi desain. Modul pembelajaran IPA berbasis example non example materi pemanasan global dikembangkan dinilai oleh para ahli dengan persentase yaitu (ahli materi) 90\% dan 88, 75\%, (ahli bahasa) 89,3\% dan 84\%. dan (ahli desain/media) $80 \%$ dan $76.25 \%$ dengan kategori sangat layak, layak, sangat layak. Uji respon siswa dilakukan terhadap 23 orang siswa kelas VIII yang ada di SMPN 05 Seluma dengan presentase 4,49 (kategori sangat setuju) . Dan uji coba 2 orang respon guru IPA dengan presentase $91.33 \%$ (sangat setuju). Kategori sangat layak dan sangat setuju. Berdasarkan hasil dari uji kelayakan dan kepraktisan tersebut maka modul pembelajaran berbasis example non example materi pemanasan global dinyatakan layak dan siswa setuju sebagai media pembelajaran materi pemanasan global untuk kelas VII SMPN 05 Seluma.
\end{abstract}

Kata kunci : modul, example non example, pemanasan global

\begin{abstract}
ABTRACT
This research was conducted at SMPN 05 Seluma by examining 23 children in grade VIII in the first semester of the 2020/2021 school year. The purpose of this research is to develop a feasible and practical example-based learning module that is used after validation by several experts and test responses by students and teachers. The research method uses the Borg \& Gall development model which is then limited to 8 stages and is limited to producing the stages of developing the science learning module, namely: Potential and problems, data collection, product design, design validation, material validation, language validation, product validation, student response testing, Product revision. This research is limited to the limited field trial stage, namely the feasibility and practicality of the module. The instruments used were a module feasibility test questionnaire and a student and teacher response questionnaire. The research subjects were 5 lecturers of IAIN Bengkulu and 1 subject teacher consisting of 2 language validations, 2 material validations, 2 design validations. The science learning module based on example non example, the material on global warming developed was assessed by experts with a percentage of $90 \%$ and $88,75 \%$ (linguist) $89.3 \%$ and $84 \%$. and (design / media experts) $80 \%$ and $76.25 \%$ with very decent, decent, very decent categories. The student response test was carried out on 23 class VIII students at SMPN 05 Seluma with a percentage of 4.49 (strongly agree category). And testing 2 science teacher responses with a percentage of $91.33 \%$ (strongly agree). Very worthy category and very much agree. Based on the results of the feasibility and practicality tests, the example non example based learning module, global warming material was declared feasible and the students agreed to be a learning medium for global warming material for class VII SMPN 05 Seluma.
\end{abstract}

Keywords: "module, example non example, global warming"

\section{PENDAHULUAN}

Pendidikan merupakan hal yang dibutuhkan oleh setiap individu. Pendidikan dapat diartikan sebagai usaha sadar untuk menjadikan diri lebih baik. dalam kamus besar bahasa Indonesia disebutkan bahwa pendidikan adalah proses pengubahan sikap dan tata laku seseorang atau sekelompok orang dalam usaha mendewasakan manusia melalui upaya pengajaran dan pelatihan. 
Undang-undang No. 20 Tahun 2003 tentang Sistem Pendidikan Nasional menyatakan bahwa pendidikan adalah usaha sadar dan terencana untuk mewujudkan suasana belajar dan proses pembelajaran agar siswa secara aktif mengembangkan potensi dirinya untuk memiliki kekuatan spiritual, keagamaan, pengendalian diri, kepribadian, kecerdasan, akhlak mulia serta keterampilan yang diperlukan dirinya, masyarakat, bangsa, dan Negara (Maulana, 2017).

Ilmu pendidikan begitu penting, sehingga terdapat beberapa ayat di dalam Al-qur'an yang menjelaskan tentang keutamaan orang-orang yang memiliki ilmu pengetahuan, sebagaimana yang digambarkan Allah SWT dalam salah satu firman-Nya yaitu Q.S Al-Mujaadilah ayat 11:

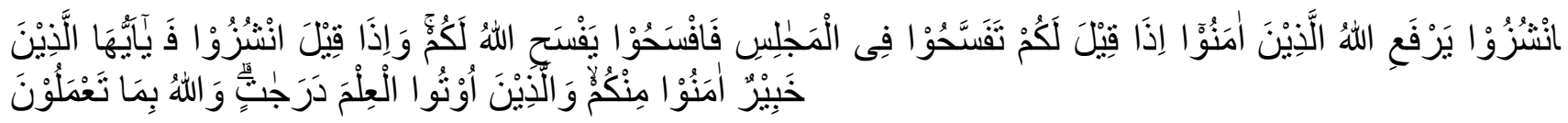

Terjemahnnya:

Wahai orang-orang yang beriman! Apabila dikatakan kepadamu, "Berilah kelapangan di dalam majelis-majelis," maka lapangkanlah, niscaya Allah akan memberi kelapangan untukmu. Dan apabila dikatakan, "Berdirilah kamu," maka berdirilah, niscaya Allah akan mengangkat (derajat) orang-orang yang beriman di antaramu dan orang-orang yang diberi ilmu beberapa derajat. Dan Allah Mahateliti apa yang kamu kerjakan. (Al-Qur'an Terjemah Per-kata)

Surah Al-Mujaadalah ayat $11 \mathrm{di}$ atas menjelaskan bahwa Allah tidak menegaskan bahwa orang yang berilmu akan ditinggikan derajatnya melainkan yang dimaksud adalah Alladzina Utu Al$\mathrm{ilm} /$ yang diberi pengetahuan adalah yang beriman dan menghiasi diri mereka dengan pengetahuan. Orang yang beriman terbagi atas dua kelompok besar yang pertama sekedar beriman dan beramal saleh dan yang kedua beriman dan beramal saleh serta memiliki pengetahuan. Derajat kelompok kedua ini lebih tinggi bukan saja karena nilai ilmu yang disandangnya tetapi juga amal dan pengajarannya kepada pihak lain, baik secara lisan, atau tulisan, maupun keteladanan. Ilmu yang dimaksud bukan saja ilmu agama, tetapi ilmu apapun yang bermanfaat.

Di sisi lain, ilmu pengetahuan terhadap peserta didik memiliki pengaruh besar mengenai perubahan pola pikir dan tingkah laku. Dengan ilmu pengetahuan, mereka telah mampu memperlihatkan kualitas diri dan mengetahui apa yang menjadi potensi diri mereka. Permasalahan utama yang dihadapi oleh dunia pendidikan dalam mengembangkan potensi peserta didik adalah permasalahan proses pembelajaran. Proses pembelajaran yang terjadi di dalam kelas lebih diutamakan pada perolehan kemampuan kognitif, peserta didik lebih dituntut untuk menghafal pelajaran yang tanpa diminta untuk memahami dan menghubungkan pelajaran yang diperolehnya untuk diterapkan dalam kehidupan sehari-hari, sehingga ketika peserta didik lulus dari sekolah mereka pandai secara teori, tetapi tidak mampu mengaplikasikannya.

Untuk mengatasi permasalahan di atas, pembelajaran saat ini sudah banyak sekali model-model yang dapat digunakan oleh guru untuk menunjang penyampaian materi yang akan disampaikan kepada peserta didik. Salah satunya adalah dengan menggunakan bahan pembelajaran yang penyampaiannya dapat dikolaborasikan dengan model pembelajaran. Bahan pembelajaran yang dapat digunakan guru untuk memudahkan penyampaian materi kepada peserta didik dapat berupa LKS, modul, dan beberapa bahan pembelajaran lainnya.

Dari beberapa bahan pembelajaran yang ada, peneliti memilih modul untuk dijadikan sebagai alat yang akan digunakan untuk menyampaikan meteri pembelajaran.

Modul merupakan salah satu bahan ajar yang dapat membantu siswa dalam memahami materi pembelajaran. Pembelajaran dengan modul memungkinkan siswa memiliki kecepatan lebih tinggi dalam menyelesaikan kompetensi dasar.

Modul disajikan dengan bahasa yang baik, menarik, dan dilengkapi dengan ilustrasi, hal ini dapat memotivasi siswa untuk memahami pembelajaran. Media pembelajaran dari media cetak yang memegang peranan penting dalam proses pembelajaran. Modul pembelajaran merupakan suatu paket program yang disusun dalam bentuk satuan tertentu dan desain sedemikian rupa guna kepentingan belajar siswa. Satu paket modul biasanya memiliki komponen petunjuk guru, lembar kegiatan siswa, lembar kerja siswa, kunci lembar kerja siswa, lembaran tes dan kunci lembar tes. 
Dengan ini penelitian meneliti berupa modul pembelajaran IPA berbasis example non example (Paktur dan Wibowo, 2013).

Example Non Example merupakan startegi pembelajaran yang menggunakan gambar sebagai media untuk menyampaikan materi pembelajaran. Model pembelajaran Example Non-Example merupakan model pembelajaran yang menggunakan gambar sebagai media pembelajaran. Model pembelajaran Example Non Example merupakan sebuah langkah untuk mensiasati agar siswa dapat mendefinisikan sebuah konsep. Adapun strategi yang digunakan bertujuan untuk mempersiapkan siswa secara cepat dengan menggunakan dua hal yang teridri dari example (contoh suatu materi yang akan dibahas) dan Non-Example (contoh materi yang tidak dibahas), dan meminta siswa untuk mengklasifikasi keduanya sesuai konsep yang ada (Saleha, O. W., dkk, 2016).

Hasil observasi yang dilakukan oleh peneliti di kelas VII di SMPN 05 Kabupaten Seluma di temukan bahwa kondisi sarana dan prasarana di SMPN 05 Seluma dapat dikategorikan sudah cukup lengkap. Contohnya buku-buku paket pelajaran siswa untuk membantu kelancaran proses pembelajaran dan charta sudah tersedia di perpustakaan sekolah. Buku-buku koleksi yang dimiliki sekolah adalah buku-buku yang sudah sesuai dengan kurikulum pendidikan saat ini dan jumlahnya sudah cukup sebanding dengan jumlah siswanya. Namun dalam proses pembelajaran charta serta bahan pendukung lainnya yang dapat digunakan dalam proses pembelajaran mungkin belum digunakan secara optimum, selama ini proses pembelajaran pendidik menggunakan metode ceramah saja tanpa menggunakan model pembelajaran sebagai penunjang dalam proses pembelajaran IPA. Hal inilah yang menyebabkan materi ini sesuatu yang dianggap sulit bagi sebagian besar peserta didik dan tentu saja menyebabkan hasil belajar mereka pada materi pemanasan global masih belum sesuai harapan dan dengan adanya melihat kenyataan ini maka sangat diperlukan penggunaan model pembelajaran dalam proses pembelajaran IPA agar dapat mempermudah dalam proses pembelajaran siswa dalam materi pokok pemanasan global sehingga hasil belajar siswa pun akan meningkat. Maka berdasarkan kondisi tersebut dibutuhkan alternatif model pembelajaran yang dapat meningkatkan motivasi belajar siswa dan hasil belajar.

\section{METODE PENELITIAN}

Jenis metode dalam penelitian ini peneliti mengunakan metode penelitian dan pengembangan (R\&D). R\&D adalah metode penelitian yang digunakan untuk menghasilkan produk tertentu, dan menguji keefektifan produk tersebut. Model pengembangan menurut Borg \& Gall dalam buku Sugiyono. Pengertian penelitian dan pengembangan menurut Borg and Gall (1983) adalah suatu proses yang dipakai untuk mengembangkan dan memvalidasi produk pendidikan. Tahapan proses penelitian dan pengembangan biasanya membentuk siklus yang konsisten untuk menghasilkan suatu produk tertentu sesuai dengan kebutuhan, melalui langkah desains awal produk, uji coba produk awal untuk menemukan berbagai kelemahan, diuji cobakan kembali, diperbaiki sampai akhirnya ditemukan produk yang dianggap ideal. (Sugiyono, 2013).

Untuk dapat menghasilkan produk tertentu digunakan penelitian yang bersifat analisis kebutuhan dan untuk menguji keefektifan produk tersebut supaya berfungsi sebagai media pembelajaran bagi siswa pada materi pemanasan global maka diperlukan penelitian untuk menguji keefektifan produk tersebut. Jadi penelitian dan pengembangan bersifat longitudinal (bertahap bisa multy years).

\subsection{Tempat dan Waktu Penelitian}

Tempat dilaksanakan penelitian ini adalah di SMPN 05 Seluma. Waktu yang digunakan dalam pelaksanaan penelitian pengembangan modul pembelajaran IPA materi pemanasan global berbasis example non example kelas VII di SMPN 05 Seluma adalah sebagai berikut: (1) Tahap pendefinisian dan tahap perancangan dilakukan pada bulan juni-juli 2020. (2) Tahap pengembangan dan tahap penyebaran dilakukan pada bulan September-Oktober 2020.

\subsection{Populasi dan Sampel Penelitian}

Populasi pada penelitian ini adalah siswa SMPN 05 Seluma. Sampel penelitian diambil pada siswa kelas VIII yang terdiri 23 orang siswa.

\subsection{Instrumen Pengumpulan Data}


Angket validasi Modul Pembelajaran IPA Berbasis Example Non Example yang terdiri dari: (1) Angket Validasi Ahli Materi; (2) Agket Validasi Ahli Bahasa; dan (3) Angket Validasi Ahli Media/Desain.

Angket kepraktisan Modul Pembelajaran IPA Berbasis example non example, terdiri dari: (1) Angket Respon Guru dan (2) Angket Respon Siswa.

\subsection{Analisis Data}

Peneliti membuat lembar validasi yang berisikan pernyataan. Kemudian validator mengisi angket dengan memberikan tanda centang pada kategori yang telah disediakan oleh peneliti berdasarkan skala likert yang terdiri dari 5 skor penilaian sebagai berikut: Tabel 1. Skor Penilaian Validasi Ahli

\begin{tabular}{cc}
\hline Keterangan & Skor \\
\hline Sangat Baik (SB) & 5 \\
Baik (B) & 4 \\
Cukup (C) & 3 \\
Kurang (K) & 2 \\
Sangat Kurang (SK) & 1 \\
\hline
\end{tabular}

Hasil validasi yang sudah tertera dalam lembar validasi modul akan dianlisis menggunkan rumus sebagai berikut:

$$
\mathrm{P}=\frac{F}{N} \mathrm{X} 100 \%
$$

Dimana $\mathrm{P}$ adalah angka persentase data angket, $\mathrm{f}$ adalah jumlah skor yang diperoleh, dan $\mathrm{N}$ adalah jumlah skor maksimum (Herawati, 2016). Selanjutnya persentase kelayakan yang didapatkan kemudian diinterpretasikan ke dalam kategoti berdasarkan Tabel berikut:

Tabel 2. Kriteria Kelayakan

\begin{tabular}{cc}
\hline Penilaian & Kriteria Interpretasi \\
\hline $80 \leq \mathrm{P} \leq 100 \%$ & Sangat Layak \\
$60 \leq \mathrm{P}<80 \%$ & Layak \\
$40 \leq \mathrm{P}<60 \%$ & Cukup Layak \\
$20 \leq \mathrm{P}<40 \%$ & Tidak Layak \\
$0 \leq \mathrm{P}<20 \%$ & Sangat Tidak Layak \\
\hline
\end{tabular}

Bahan ajar berbentuk modul dinyatakan layak secara teoritis apabila persentase kelayakan adalah $\geq$ $61 \%$.

Teknik analisis hasil angket respon guru dan peserta didik berlandaskan skala Likert yang terdiri atas 5 ukuran penilaian sebagai berikut:

Tabel 3. Skor Angket

\begin{tabular}{lc}
\hline Pilihan jawaban & Pilihan jawaban Skor \\
\hline Sangat setuju (SS) & 5 \\
Setuju (S) & 4 \\
Kurang setuju (KS) & 3 \\
Tidak setuju (TS) & 2 \\
Sangat tidak setuju (STS) & 1 \\
\hline
\end{tabular}

Hasil angket respon guru dan peserta didik dianalisa menggunakan rumus sebagai berikut:

$$
\mathrm{P}=\frac{F}{N} \mathrm{X} 100 \%
$$

dimana $\mathrm{P}$ adalah angka persentase data angket, $\mathrm{F}$ adalah jumlah skor yang diperoleh, dan $\mathrm{N}$ adalah jumlah skor maksimum.

\section{HASIL DAN PEMBAHASAN}

\subsection{Hasil Pengembangan}

Hasil utama dari penelitian pengembangan ini adalah modul pembelajaran IPA berbasis example non example materi pemanasan global untuk kelas VII. Hasil dari setiap tahapan prosedur pengembangan yang dilakukan adalah sebagai berikut.

\subsubsection{Tahap pendahuluan}


Dengan melakukan prasurvei pada sekolah sebagai tempat uji coba. Kegiatan dilakukan dengan pengamatan dan penyebaran angket kebutuhan terhadap guru dan siswa mengenai bahan ajar yang tersedia disekolah dan diproleh informasi bahwa siswa dan guru mengalami kesulitan belajar dan mengajar dikarna kurangnya media pembelajaran materi pemanasan global. Usaha yang dilakukan oleh siswa dengan membeli buku lainya untuk mendukung belajar, tetapi tidak semua siswa melakukan upaya tersebut.

\subsubsection{Tahap Pengembangan}

Penulisan modul pembelajaran IPA ini terbagi menjadi 4 tahapan yang berurutan. Tahapan pertama yaitu pengumpulan bahan yang akan digunakan dalam sub pokok bahasan. Bahan-bahan yang digunakan dalam sub pokok bahasan dikumpulkan dari berbagai sumber, mulai dari buku dan internet. Bahan-bahan tersebut diantaranya materi, gambar, info sains, dan yang berkaitan dengan materi.

Tahap kedua pembuatan layout atau tata letak tiap halaman dalam modul.

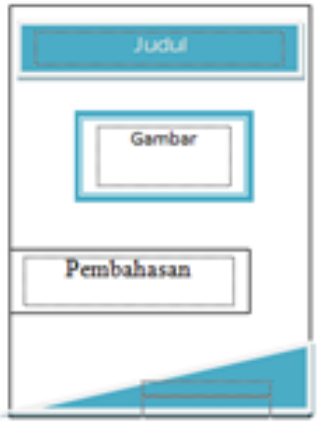

(a)

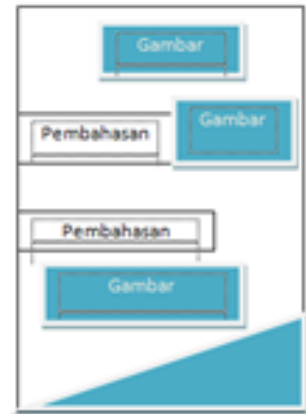

(b)

Gambar 1. Lay out halaman 9 (a), dan lay out halaman 14 (b)

Tahap ketiga yaitu proses mixing atau penggabungan tiap komponen atau bahan dalam sebuah sub pokok bahasan.

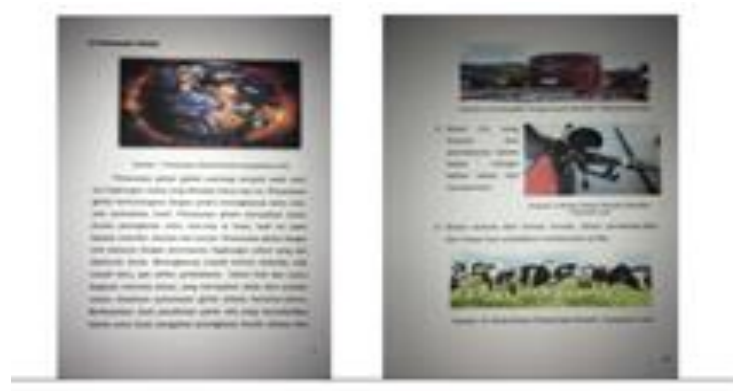

(a) (b)

Gambar 2. Lay out halaman 9 (a), dan lay out halaman 14 (b)

Tahap keempat yaitu finishing atau tahap akhir yang berfungsi untuk memperindah tampilan sebuah halaman, mulai dari format huruf, komposisi warna, komposisi gambar, dan efek tiap komponennya.



Gambar 3. Hasil finishing halaman 9 (a), dan hasil finishing halaman 14 (b)

\subsection{Data Hasil Uji Validasi Kelayakan}


Data hasil uji validasi produk meliputi data hasil validasi ahli materi, ahli bahasa dan ahli desain/media sebagai berikut.

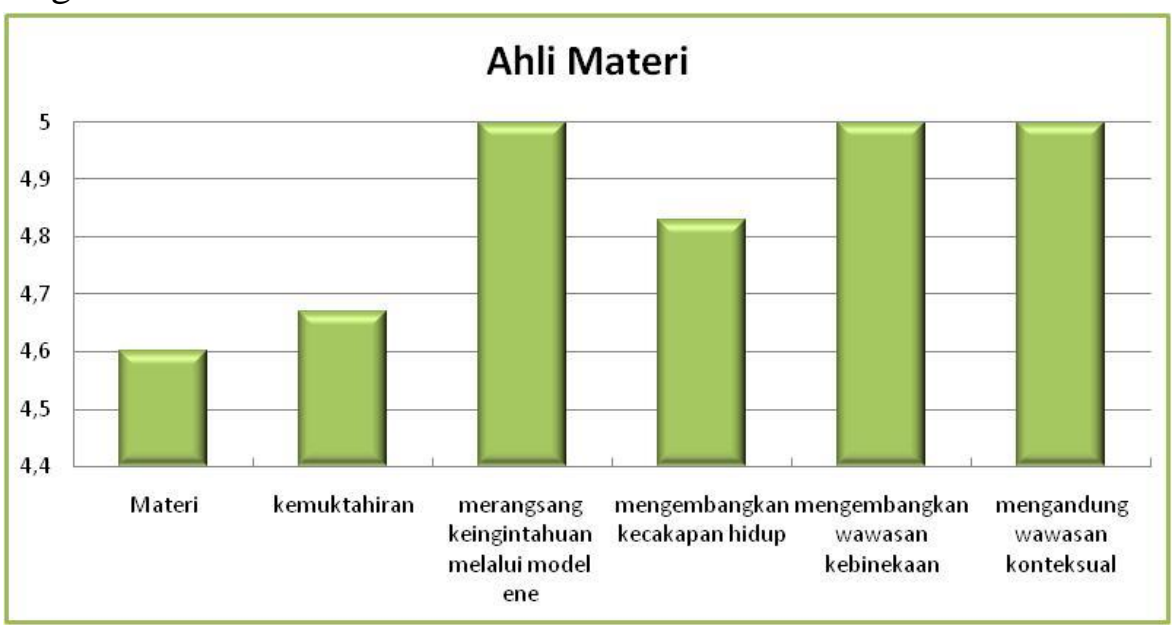

Gambar 4. Grafik validasi angket untuk ahli materi

Dari gambar 4. komponen materi memiliki nilai 4,6 hal ini berarti modul pembelajaran sebagai media pembelajaran IPA materi pemanasan global memiliki nilai baik untuk keterpaduan antar materi, akurasi fakta, kebenaran konsep teori, serta akurasi prosedur/metode. Komponen kemutakhiran memiliki nilai 4,67 hal ini berarti modul pembelajaran berbasis example non example materi pemanasan global sebagai media pembelajaran IPA materi pemanasan global memiliki nilai baik untuk kesesuaian dengan perkembangan ilmu, keterkinian/ketermasaan dan rujukan termasa. Komponen merangsang keingintahuan melalui media memperoleh nilai 5 hal ini berarti modul pembelajaran sebagai media pembelajaran IPA materi pemanasan global memiliki nilai baik untuk menumbuhkan rasa ingin tahu, menumbuhkan jiwa konservasi, serta mendorong mencari informasi lebih jauh. Komponen mengembangkan kecakapan hidup memperoleh nilai 4,83 hal ini berarti modul pemanasan sebagai media pembelajaran IPA materi pemanasan global memiliki nilai baik untuk mengembangkan kecakapan personal, mengembangkan kecakapan social, serta mengembangkan kecakapan akademik. Komponen mengembangkan wawasan kebenekaan hidup memperoleh nilai 5 hal ini berarti pemanasan global sebagai media pembelajaran IPA materi pemanasan global memiliki nilai baik untuk aspirasi terhadap materi pemanasan global dengan lingkungan dan rasa syukur peserta didik kepada Tuhan Yang Maha Esa. Komponen mengandung wawasan kontekstual memperoleh nilai 5 hal ini berarti modul pembelajaran sebagai media pembelajaran IPA materi pemanasan global memiliki nilai sangat baik untuk menyajikan contohcontoh dari lingkungan lokal tentang materi pemanasan global.

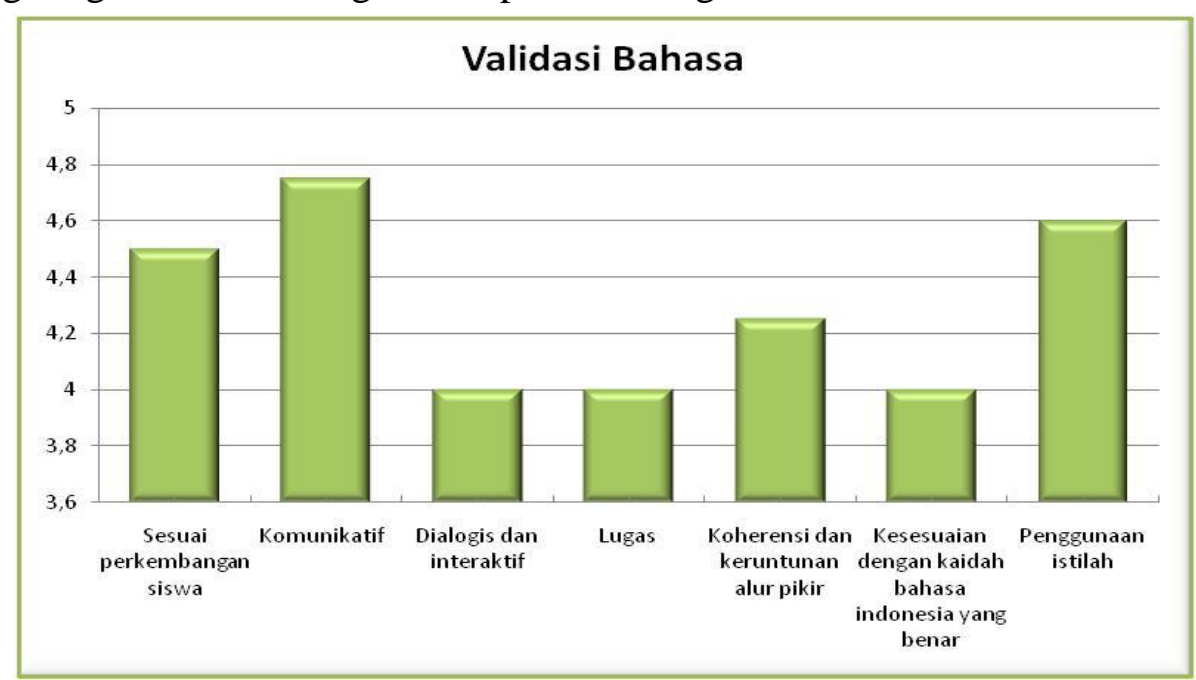

Gambar 5. Grafik validasi dari ahli bahasa

Dari gambar 5. menujukkan komponen kesesuaian dengan perkembangan siswa memiliki nilai 4,5 hal ini berarti modul pembelajaran berbasis example non example sebagai media pembelajaran 
IPA materi pemanasan global memiliki nilai baik untuk kesesuaian dengan tingkat perkembangan berfikir siswa dan kesesuaian dengan tingkat perkembangan sosial emosional siswa. Komponen komunikatif memiliki nilai 4,75 hal ini berarti modul pembelajaran berbasis example non example sebagai media pembelajaran IPA materi pemanasan global memiliki nilai baik untuk keterpahaman siswa terhadap pesan dan kesesuaian ilustrasi permasalahan dengan substansi pesan. Komponen dialogis dan interaktif memiliki nilai 4,00 hal ini berarti modul pembelajaran berbasis example non example sebagai media pembelajaran IPA materi pemanasan global memiliki nilai baik untuk kemampuan memotivasi siswa untuk merespon pesan dan menciptakan komunikasi interaktif. komponen lugas memiliki nilai 4,00 hal ini berarti modul pembelajaran berbasis example non example sebagai media pembelajaran IPA materi pemanasan global memiliki nilai baik untuk ketetapan struktur kalimat dan kebakuan istilah.

Komponen koherensi dan keruntutan alur pikir memiliki nilai 4,25 hal ini berarti modul pembelajaran berbasis example non example sebagai media pembelajaran IPA materi pemanasan global memiliki nilai baik untuk keutuhan makna dalam alenia dan keteraturan antar alenia/kalimat. Komponen kesesuaian dengan kaidah bahasa indonesia yang benar memiliki nilai 4,00 hal ini berarti modul pembelajaran berbasis example non example sebagai media pembelajaran IPA materi pemanasan global memiliki nilai baik untuk ketepatan tata bahasa dan ketetapan ejaan. Komponen pengunaan istilah dan simbol/lambang memiliki nilai 4,67 hal ini berarti modul pembelajaran berbasis example non example sebagai media pembelajaran IPA materi pemanasan global memiliki nilai baik untuk konsistensi pengunaan istilah, Konsistensi pengunaan simbol/lambang serta konsistensi pengunaan nama ilmiah/asing. Dari hasil rata-rata di atas menunjukkan bahwa modul pembelajaran berbasis example non example sebagai media pembelajaran IPA materi pemanasan global untuk kelas VII ini layak di gunakan sebagai bahan ajar. Hal ini sesuai dengan Galih Roby Mahendra (Skripsi 2016 ) dalam jurnal "pengembangan model example non example dengan make a macth " yang menunjukan bahwa model example non example menunjukkan terbukti efektif setelah dilakukan uji coba pada siswa.

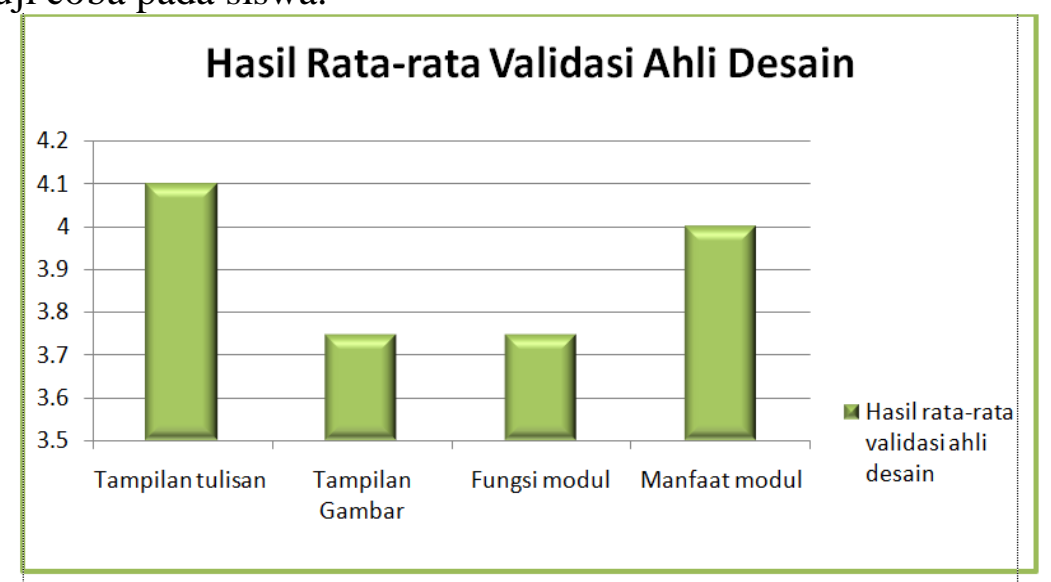

Gambar 6. Grafik hasil validasi dari ahli bahasa

Dari gambar 6 diatas komponen tampilan tulisan memiliki nilai 4,1 hal ini berarti modul pembelajaran IPA berbasis example non example materi pemanasan global untuk kelas VII memiliki nilai baik untuk penulisan judul modul, ukuran huruf pada tulisan, pengunaan kata, dan kejelasan tulisan. Komponen tampilan gambar memiliki nilai 3,75 hal ini berarti modul pembelajaran IPA berbasis example non example materi pemanasan global memiliki nilai baik untuk bentuk gambar, ukuran gambar, kesesuaian gambar dengan tulisan dan variasi gambar.

Komponen fungsi modul pembelajaran IPA berbasis example non example materi pemanasan global untuk kelas VII memiliki nilai 3,75 hal ini berarti modul pembelajaran IPA berbasis example non example materi pemanasan global memiliki nilai baik untuk modul pembelajaran IPA berbasis example non example materi pemanasan global untuk kelas VII sebagai sumber belajar, bahasa penyampaian yang digunakan dalam modul dapat dipahami peserta didik, modul pembelajaran berbasis example non example mampu menarik dan memfokuskan perhatian peserta didik, dan 
modul pembelajaran IPA berbasis example non example materi pemanasan global untuk kelas VII mendorong siswa untuk melakukan kegiatan pembelajaran sehingga tujuan pembelajaran tercapai.

Komponen manfaat modul pembelajaran berbasis example non example memiliki nilai 4,00 hal ini berarti modul pembelajaran IPA berbasis example non example materi pemanasan global memiliki nilai baik untuk modul pembelajaran menarik komunikasi yang efektif antara guru dan siswa, modul ini memberikan kesempatan kepada siswa untuk belajar mandiri, kesesuaian modul pembelajaran dengan tujuan pembelajaran yang ingin dicapai, dan kesesuaian modul pembelajarn dengan kondisi dan strategi yang digunakan.

Dari hasil rata-rata di atas bahwa modul pembelajaran IPA berbasis example non example materi pemanasan global untuk kelas VII ini layak digunakan menurut penelitian Galih Roby Mahendra (Skripsi 2016) berjudul Pengembangan model example non example dengan make A match dalam meningkatkan hasil belajar siswa menyimpulkan bahwa adanya peningkatan hasil belajar pada siswa berdasarkan prauji coba menggunakan model example non example hasil belajar siswa yang mencapai nilai KKM $(\geq 60)$ sebesar $21,92 \%$, setelah dilakukan uji coba tahap 1 meningkat menjadi $40,96 \%$, dan pada uji coba tahap II meningkat menjadi $76,5 \%$. Hal ini menunjukan bahwa produk model example non example membuat daya tarik belajar siswa sehingga siswa dapat memahami materi pemanasan global dan modul pembelajaran ini layak di gunakan dengan nilai 4,15 kategori baik dan layak.

Berdasarkan penilaian dari 2 ahli bahasa, 2 ahli materi, dan 2 ahli desain, maka modul pembelajaran IPA berbasis example non example materi pemanasan global untuk kelas VII mendapatkan nilai dari ahli bahasa yaitu 5 dan 5 (sangat baik), ahli materi 5 dan 5 (sangat baik), ahli desain 5 dan 4 (sangat baik), tahap selanjutnya yaitu merevisi modul pembelajaran sesuai dengan saran perbaikan oleh 6 validator untuk masuk pada tahap uji coba produk.

\subsection{Hasil Uji Coba kepraktisan}

Data hasil uji kepraktisan produk meliputi data hasil guru dan siswa yaitu aspek keperaktisan. Dengan kriteria penilaian yang di gunakan adalah sebagai berikut: Skor 1 apabila kelayakan modul pembelajaran Sangat Kurang Baik (SK), Skor 2 apabila kelayakan modul pembelajaran Kurang Baik (K), Skor 3 apabila kelayakan modul pembelajaran Cukup Baik (C), Skor 4 apabila kelayakan modul pembelajaran Baik (B), dan Skor 5 apabila kelayakan modul pembelajaran Sangat Baik (SB).

Nilai rata-rata respon siswa terhadap modul pembelajaran IPA berbasis example non example materi pemanasan global untuk kelas VII 4,49 dan nilai respon guru 5 sehingga modul ini dapat dikatakan siswa setuju menggunakan modul pembelajaran IPA berbasis example non example materi pemanasan global untuk kelas VII sebagai media pembelajaran IPA.

Tabel 4. Hasil uji coba kepraktisan

\begin{tabular}{lllll}
\hline Responden & Skor & Persentase & Rata-rata & Kategori \\
\hline Siswa 23 & 90 & $88,90 \%$ & 4,9 & Baik \\
Guru 1 & 68 & $90,67 \%$ & 5 & Sangat Baik \\
Guru 2 & 68 & $90,67 \%$ & 5 & Sangat Baik \\
Jumlah & 136 & $90,67 \%$ & 5 & Sangat Baik \\
\hline
\end{tabular}

\section{SIMPULAN DAN SARAN}

\subsection{Simpulan}

Berdasarkan hasil analisis data dan pembahasan yang telah dilakukan dapat disimpulkan sebagai berikut: (1) Modul pembelajaran IPA berbasis example non examplemateri pemanasan global dikembangkan dengan mengacu 10 tahapan metode research and development oleh Borg \& Gali yang kemudian dibatasi hingga 8 tahapan dan dibatasi menghasilkan tahapan pengembangan modul pembelajaran IPA yaitu: Potensi dan masalah, Pengumpulan data, Desain produk, Validasi desain, Validasi materi, Validasi bahasa, Validasi produk, Uji respon siswa, Revisi produk. (2) Modul pembelajaran IPA berbasis example non example materi pemanasan global dikembangkan dinilai oleh para ahli dengan persentase yaitu ahli materi 98,67\% (sangat layak), ahli bahasa 81,25\% (layak) dan ahli desain/media 78,12\% (layak). (3) Uji keperaktisan siswa dilakukan terhadap 23 
orang siswa kelas VIII yang ada di SMPN 05 Seluma dengan presentase 86,7 \% . Dan uji coba 2 orang respon guru IPA dengan presentase $91.33 \%$ (sangat praktis). Kategori sangat layak dan praktis. Berdasarkan hasil dari uji kelayakan dan kepraktisan tersebut maka modul pembelajaran berbasis example non example materi pemanasan global dinyatakan layak dan praktis untuk diaplikasikan kepada peserta didik siswa kelas VIII SMPN 05 Seluma.

\subsection{Saran}

Berdasarkan hasil perolehan penelitian, maka penelitian dapat menyampaikan beberapa saran sebagai berikut: (1) Bagi siswa penelitian ini diharapkan sebagai salah satu sumber belajar berupa modul pembelajaran pada materi pemanasan global. (2) Bagi guru penelitian ini diharapkan dapat dijadikan acuan selanjutnya untuk lebih menekan pada pembelajaran dengan memberikan contoh yang kongkret. (3) Bagi peneliti lain dapat mencoba mengembangkan bahan ajar serupa pada materi yang berbeda sesuai kebutuhan.

\section{DAFTAR PUSTAKA}

Al-Qur'an Terjemah Per-kata. Departemen Agama RI. Yayasan Penyelenggaraan Penerjemahan/Penafsir Al-Qur'an (Revisi Terjemah Oleh Lajnah Pentashih Mushaf Al-Qur'an Depertemen Republik Indonesia). Bandung: Syaamil Internasional.

Herawati. 2016. Pengembangan Media Keanekaragaman Aves Sebagai Sumber Belajar Biologi. Jurnal Lentera Pendidikan LPPM UM Metro 1, No.1, hlm. 32.

Maulana, Marwah Ahmad. 2017. Pengembangan Media Pembelajaran Bebrasis Leaflet Pada Materi Sistem Sirkulasi Kelas Xi Man 1 Makassar. Skripsi. Fakultas Tarbiyah Dan Keguruan Universitas Islam Negri (Uin) Alauddin Makasar.

Paktur, Muhammad, dan Wibowo, T.W. 2013. Pengembangan Modul Pembelajaran Autocad untuk Meningkatkan Efektivitas Pembelajaran Siswa Kelas X TPM Di SMKN 1 Sidoarjo. Jurnal JPTM 1, No. 3, hlm. 87.

Saleha, O. W., dkk. 2016. Penerapan Model Pembelajaran Example Non Example Untuk Meningkatkan Aktivitas Dan Pemahaman Konsep Siswa Kelas VII SMP Negri 4 Parigi Pada Materi Klarifikasi Makhluk Hidup. Jurnal Ampibi 1(1).

Sugiyono. 2013. Metode Penelitian kuantitatif Kualitatif dan R\&D. Alfabet: Bandung. 